\title{
Integrating mobile phone technologies into labor-market intermediation: a multi-treatment experimental design
}

\author{
Ana C Dammert ${ }^{1,2}$, Jose Galdo $3,2^{*}$ and Virgilio Galdo
}

\author{
* Correspondence: \\ jose_galdo@carleton.ca \\ ${ }^{3}$ Department of Economics and \\ School of Public Policy and \\ Administration, Carleton University, \\ 1125 Colonel by Drive, Ottawa, \\ Canada \\ ${ }^{2}$ IZA, Bonn, Germany \\ Full list of author information is \\ available at the end of the article
}

\begin{abstract}
This study investigates the causal impacts of integrating mobile phone technologies into traditional public labor-market intermediation services on employment outcomes. By providing faster, cheaper and up-to-date information on job vacancies via SMS, mobile phone technologies might affect the rate at which offers arrive as well as the probability of receiving a job offer. We implement a social experiment with multiple treatments that allows us to investigate both the role of information channels (digital versus non-digital) and information sets (restricted [public] versus unrestricted [public/private]). The results show positive and significant short-term effects on employment for public labor-market intermediation. While the impacts from traditional labor-market intermediation are not large enough to be statistically significant, the unrestricted digital treatment group shows statistically significant short-term employment effects. As for potential matching efficiency gains, the results suggest no statistically significant effects associated with either information channels or information sets.

JEL classification codes: $13, \mathrm{~J} 2$

Keywords: Mobile phones; Labor-market intermediation; ICT; Field experiments; Peru
\end{abstract}

\section{Introduction}

Information, though often costly or incomplete in reality, is central to the functioning of markets (e.g., Stigler 1961). Economists have long emphasized that improvements in information have the power to impact market performance and welfare, particularly in developing settings where informational problems are seen as key barriers for growth and development (e.g., Aker 2010). Labor market transactions are not an exception as they are characterized by high levels of mismatch, coordination problems, and asymmetric information affecting workers and firms alike (e.g., Autor 2001). Yet, traditional labor-market intermediaries (LMIs), such as public employment offices and temporary help agencies, which aim to reduce search costs and adverse selection problems, remain understudied in both developed and developing settings (Autor 2009).

The unprecedented expansion of Information and Communication Technologies (ICT) in the last two decades has invigorated research in this area motivated by the emergence of a new array of LMIs, such as online job boards, social media sites, and e-recruiting firms. Evidence, largely based on U.S. data, has shown how the diffusion

\section{管 Springer}

(c) 2015 Dammert et al. This is an Open Access article distributed under the terms of the Creative Commons Attribution License (http://creativecommons.org/licenses/by/4.0), which permits unrestricted use, distribution, and reproduction in any medium, provided the original work is properly credited. 
of the Internet has allowed the emergence of new LMIs (Stevenson 2009, Nakamura et al. 2009, Bagues and Sylos 2009), leading to a reallocation of job search effort (Stevenson 2009, Kuhn and Mansour 2011) and more diversified search behavior (Kroft and Pope 2009, Cahuc and Fontaine 2009).

While this promising research has addressed the impacts of Internet access on search behavior and unemployment spells, nothing is yet known about the role of mobile phone technologies on the efficiency of the labor markets. The aim of this study is to provide evidence, analysis and insights on the causal impacts of (digital) public labormarket intermediation in a developing-country setting. Despite its importance, there is essentially no empirical evidence thus far on the impacts of mobile phone technologies on labor-market outcomes.

A distinctive feature of this study is its experimental design. We use as a case study the public LMI system in Peru, a country that adopted an innovative e-government initiative in labor intermediation ${ }^{1}$. We implement a social experiment with multiple treatments as part of regular (non-experimental) public labor intermediation services. From June 22, 2009 to September 1, 2009, the experimental sample was selected at the initial registration filing for the normal inflow of applicants into Lima. Jobseekers that signed up to receive public labor-market intermediation were randomly assigned to four treatment groups according to two information channels (i.e., digital and non-digital intermediation) and the scope of information they received (i.e., restricted [public] and unrestricted [public/private] information sets). The restricted set only considers SMS messages regarding job positions from firms that have registered within the public LMI system in Peru, while the unrestricted one considers SMS messages regarding job positions from firms inside and outside the LMI system (e.g., firms advertising job positions in newspapers).

This study addresses four specific and related topics of interest. First, we exploit unique data to analyze the determinants of digital job search in Peru by considering both Internet and mobile-phone channels. Second, we evaluate the overall effectiveness of public LMI on reducing unemployment spells and improving the match quality of workers to jobs. Evidence in this area is mixed, highly dependent on the research design and corresponds mainly to developed countries (e.g., Bishop 1993, Ashenfelter et al. 2005, Meyer 1995). Third, we compare the effectiveness of digital versus non-digital labor market intermediation within the public system. Finally, we analyze whether it is the technology or the set of information available to jobseekers that matters most. We then compare the impacts of restricted versus unrestricted information sets while holding fixed the information technology.

From a theoretical standpoint, the improvement of access to information via mobile phone service might affect the efficiency of labor market intermediation through several channels. Economic theory predicts that the larger the cost of search, the less extensive will be the searches undertaken by workers at a given wage distribution (e.g., Stigler 1962, Mortensen 1986). A direct effect of introducing mobile phones in labor market intermediation is a direct fall in search costs as workers can access relevant, up-to-date information on job vacancies via SMS. Standard search models predict that both the rate at which offers arrive and the probability of receiving a job offer will increase as a result of search costs decreasing. A second channel through which improved information via mobile phones affects the labor markets is via better arbitrage 
of prices (wages), which might lead to higher wages being offered to workers (Grossman and Stigler 1976). Information is, after all, capital that is produced at the lower cost of search and, thus, yields higher returns than what would have been received in its absence. A third channel is by better matching workers to jobs due to enhancements in search and coordination tasks (Aker and Mbiti 2010).

At the same time, some countervailing factors might affect the relevance of mobile phone service in labor-market intermediation. The rise in the number of potential matches because of reduced search costs would increase the minimum wage a worker will accept or the minimum productivity an employer will accept (Pissarides 2000, Boone and van Ours 2004). Moreover, the fall in search costs may also lead to a fall in match quality due to an excess of applications of unemployed people who belong to groups with chronic problems of employability (Autor 2001), or the emergence of crowding-out effects from traditional search methods. In the Appendix, we present for illustration purposes a theoretical model with endogenous search effort in both public and private search channels that shows uncertain effects of technology-driven search efficiency improvement on unemployment spells. The uncertainty emerges because patient jobseekers could wait for a better wage offer or because of crowding-out effects in the alternative private search channel. In all, the net effect of integrating mobile phone technologies into labor-market intermediation is an empirical question that depends on the relative strengths of these channels.

The main result shows positive and significant short-term effects on employment for public labor-market intermediation. The smallest effects are associated with traditional, non-digital intermediation, while the largest effects are associated to unrestricted SMS intermediation. However, these treatment group differences are not sufficiently large to be statistically detected. From a policy standpoint, this research shows the feasibility and value of integrating new information technologies into traditional public labormarket intermediation services.

This study speaks directly to the recent literature on digital technologies and economic development that is largely based on observational data for developed countries. By providing the first experimental evidence on the role of mobile phone technologies in connecting workers to jobs, we contribute to the understanding of how the new 'information economy' (Freeman 2002) is shaping new labor-market institutions in developing countries. Our findings contribute to an emerging body of work that reports how mobile phone services have brought new possibilities for economic development in agriculture (e.g., Aker and Fafchamps 2013, Goyal 2010), health (e.g., Dammert et al. 2014, Pop-Eleches et al. 2011), financial (e.g., Karlan et al. 2010), and fishing markets (e.g., Jensen 2007).

This study is organized as follows. Section 2 presents a background discussion about the public intermediation system in Peru; section 3 discusses the research design, treatment and treatment groups; section 4 analyzes the data and the baseline equivalence; section 5 analyzes the determinants of digital job search; section 6 reports the empirical results; and section 7 concludes.

\section{Background: public employment services in Peru}

Prior to 1996, the Peruvian Public Employment Services operated as a centralized intermediation office, hosted at the headquarters and regional branches of the Ministry of 
Labor and Social Promotion, with the aim of connecting workers to jobs. The employeremployee matching process was highly bureaucratic and done manually case-by-case without any regard for the automatization of the data collection and dissemination of the information. Not surprisingly, the job intermediation process was inefficient and costly. The average time it took for a worker to complete the registration process was 4 days after completing a battery of aptitude, knowledge, and psychometric tests (MTPS 1998). As a result, only 3 percent of active jobseekers used the public employment services in 1996, and in particular, they were those with chronic problems of employability (Chacaltana and Sulmont 2003) ${ }^{2}$.

In 1996, the Peruvian government launched an ambitious e-government initiative aimed to modernize the role of the public employment agencies. With technical and financial support from the Swiss government and the European Union, a new National Information System (SIL) was put into place to support the adoption and design of egovernment procedures, lower the administrative burden, and to improve the efficiency of the intermediation process. Bureaucratic processes were replaced by simpler and time-saving protocols, the compilation and dissemination of information changed from manual to automated matching algorithms, centralized labor-market institutions were replaced with decentralized offices through partnerships with not-for-profit institutions such as NGOs and vocational schools, and more caseworkers were hired and trained in labor-market intermediation (MTPS 1998, 1999).

This active labor-market initiative started its operations in 1998 with the introduction of CIL-PROEMPLEO, an LMI institution that offers intermediation services. Bureaucratic practices were greatly simplified as participation only requires individuals and firms to register in-person at any labor mediation office by filling a simple application form and answering a short standard labor-market survey ${ }^{3}$. This information is subsequently uploaded to SILNET, a customized informatics system of job intermediation available only through an intranet. SILNET has simplified enormously the search costs in time and effort for both firms and workers. The registration process, for instance, went from 4 days prior to 1998 to less than an hour (MTPS 1999). The computer software analyzes and matches workers' skills and experience with job openings. Once a suitable match is found, the jobseeker is contacted in person (or in some cases, by telephone or e-mail if available), in order to pick-up a letter of presentation from the Ministry of Labor with details about the job vacancy. It is worth noticing that job matches are based only on job opportunities generated from firms that have previously signed up on CIL-PROEMPLEO. Unlike other experiences, particularly in developed countries, participation in these services is voluntary given the absence of an unemployment insurance system in Peru.

Two years after the implementation of CIL-PROEMPLEO, the number of intermediated workers significantly increased. While in 1996, the total number of employeeemployer intermediation was 10,275 at the national level, it jumped to 22,764 in 1998. The corresponding numbers for metropolitan Lima, which represents more than 55 percent of the total intermediation, were 7,914 and 12,682, respectively (MTPS 1999). All in all, the number of unemployed persons using the public intermediation system has increased significantly in the past decade from three percent in 1997 to 14 percent in 2007. Likewise, the number of job vacancies that has been offered through the public system has increased by five times from 12,707 in 1997 to 66,691 in 2007. According to administrative data, the average cost for each intermediated worker reaches US\$25, 
which reflects a US\$ 191 per capita social savings with respect to the cost of using private employment agencies (MTPS 1998) ${ }^{4}$.

Administrative data also shows that the effective rate of intermediation was quite steady over time. As a percentage of applicants, CIL-PROEMPLEO was able to intermediate one-out-of-four workers, with small variations over time. As a percentage of the number of job vacancies, there is more variability ranging from 60 to 80 percent between 1998 and 2007. One potential explanation for this flattened profile is the relatively small number of job vacancies that are still advertised via the public intermediation system. Indeed, only 15 percent of firms located in metropolitan Lima were registered with CIL-PROEMPLEO in 2004 (Vera 2006).

A second wave of reforms in the operation of the Peruvian public intermediation system occurred in 2004 when the online version of CIL-PROEMPLEO started its operation in an effort to expand the adoption of information and communication technologies in the labor market ${ }^{5}$. In practice, this e-government innovation allows all registered jobseekers and firms online access to CIL-PROEMPLEO services, provided they have access to the Internet ${ }^{6}$. The main attribute of this online service is that workers and firms can upload their information and exchange suitable matches without the intervention of any caseworker. In 2005, one year after the full operation of this electronic version, 59,137 people used the online version along with more than 5,000 firms that offered 32,000 job vacancies (MTPS 2006). There is no available data, however, on the rate of labor intermediation for this component as firms and workers exchange.

\section{Research design, treatment, and treatment groups}

A primary concern in the literature of labor-market intermediation is the role of 'selection on unobservables' which has plagued non-experimental empirical studies (e.g., Meyer 1995, Kuhn and Skuterud 2004). In this setting, adverse selection is a key issue since public employment services seem to be populated with unemployed individuals with chronic problems of employability (e.g., Autor 2001 and Thomas 1997) ${ }^{7}$. A distinctive feature of this study is its experimental design with multiple treatments that minimize considerable empirical difficulties associated with both self-selection in labor intermediation and the endogenous placement of mobile phones. Early in 2009, we signed a formal agreement of cooperation with the Ministry of Labor and Social Promotion, which allowed us access, in real time, to the SILNET intranet system. The field experiment was implemented as part of the regular (non-experimental) public intermediation services, which affords two main advantages. The experimental sample is composed by new registered users of the public employment system, which greatly minimizes 'selection on unobservables' issues. Similarly, regardless of the treatment group assignment, all individuals in our sample were chosen randomly, and they did not self-select to be part of the experimental sample.

On the other hand, due to institutional restrictions we were only allowed to leave the control group individuals out of public intermediation for three months after registration in the LMI system, and thus, we were only able to measure short-run treatment effects. Starting in the fourth month, all individuals, regardless of their treatment status, were subject to the standard non-digital labor market intermediation. This particular feature will have consequences for the magnitude and interpretation of the results we analyze in section 6. 
Random assignment was carried out on a daily basis (excluding weekends and holidays) from June 22, 2009 to September 1, 2009, among new registered users to CILPROEMPLEO. The experimental sample was selected at the initial registration filing for the normal inflow of applicants in Lima after excluding registered individuals who do not own mobile phones or hold occupations with very high turnover rates; i.e., unskilled persons. Table 1 describes the main features of the treatment design. Each day, among the set of new applicants, we randomly assigned jobseekers into three different groups: non-digital treatment group, digital treatment group, and control group, following a random allocation of 30, 40, and 30 percent, respectively. The individual-level randomization protocol did not consider stratification on specific baseline characteristics due to the (daily) small samples. Registered individuals remained in the same treatment groups throughout the life of this intervention.

The non-digital treatment group was subject to the standard CIL-PROEMPLEO intermediation practices. The treatment consisted of three months of subsidized job search assistance in which individuals' labor profiles were matched with available job vacancies $^{8}$. To avoid any disruption (or caseworker bias) the names of selected members in this group were not revealed to case workers. In contrast to this treatment group, the digital treatment group was exposed to technological innovation aimed at reducing job search costs. Jobseekers assigned to this group were informed about jobmarket opportunities that match their labor profile through digital services; i.e., delivery of SMS messages to their mobile phones. The difference between traditional and digital treatment groups is that the former is mainly contacted in-person (or, by phone) following the standard protocols from CIL-PROEMPLEO, while the latter is electronically contacted via text messages. There is no other salient difference between these treatments as the regular counselor-based and mobile phone-based intermediation services follow the same protocols.

It is worth mentioning that the experimental design provided evidence only on subsidized job search assistance and does not imposed elements of job search requirements, i.e., enforcement and verification, because of the absence of an unemployment insurance system in Peru. In other studies that combine both aspects, it is more challenging to identify what aspects of the experiments induced the change in outcomes (Meyer 1995, Black et al. 2003, Ashenfelter et al. 2005). Finally, control group individuals were removed temporarily from the information system for only a period of three months.

Table 1 Experimental design

\begin{tabular}{|c|c|c|c|c|}
\hline & \multirow{3}{*}{$\begin{array}{l}\text { Traditional treatment } \\
\left(D^{T 1}\right)\end{array}$} & \multicolumn{2}{|l|}{ Digital treatment } & \multirow{3}{*}{$\begin{array}{l}\text { Control } \\
\left(D^{C}\right)\end{array}$} \\
\hline & & Restricted- & Unrestricted- & \\
\hline & & SMS $\left(D^{T 2}\right)$ & $\operatorname{SMS}\left(D^{T 3}\right)$ & \\
\hline $\begin{array}{l}\text { Random } \\
\text { allocation }\end{array}$ & $30 \%$ & $13 \%$ & $27 \%$ & $30 \%$ \\
\hline $\begin{array}{l}\text { Treatment } \\
\text { intervention }\end{array}$ & $\begin{array}{l}\text { Three months of labor- } \\
\text { market intermediation }\end{array}$ & $\begin{array}{l}\text { Three months of labor- } \\
\text { market intermediation }\end{array}$ & $\begin{array}{l}\text { Three months of labor- } \\
\text { market intermediation }\end{array}$ & None \\
\hline $\begin{array}{l}\text { Information } \\
\text { channel }\end{array}$ & No digital & SMS & SMS & None \\
\hline $\begin{array}{l}\text { Information } \\
\text { sets }\end{array}$ & Only public sources & Only public sources & Public and private sources & None \\
\hline Sample size & 345 & 188 & 303 & 354 \\
\hline
\end{tabular}


Furthermore, a key feature of CIL-PROEMPLEO is that registered jobseekers can be intermediated only with job vacancies from firms that signed up through the public intermediation system. This attribute could be inefficient as the majority of job vacancies in Lima are advertised through alternative channels such as newspaper ads, job boards or private employment agencies (Vera 2006) ${ }^{9}$. Therefore, to test whether it is the technology by itself or the set of information available to jobseekers that matters most, we implement a second set of randomization that manipulates the number of jobs on which information is available. Within the digital treatment group, individuals were randomly assigned into two different groups-the restricted-SMS treatment group and the unrestricted-SMS treatment group-following an allocation ratio of 1:1.5. The former is matched only with job-opportunities generated within the CIL-PROEMPLEO system, i.e., the public information set, while the latter is matched with both CIL-PROEMPLEO vacancies as well as job opportunities posted on alternative channels such as national newspapers ads and not-forprofit private employment agencies, i.e., public/private information sets. The comparison of these two treatment groups allows one to test the impact of expanding the set of information available to jobseekers while holding fixed the information technology.

Given the inclusion of additional information sources for the unrestricted-SMS group, the frequency of information (number of SMS messages) is expected to be higher for this group relative to the restricted-SMS treatment group. Otherwise, there is no difference in the content, wording and format of the SMS messages between both digital groups. Thus, independently of whether individuals belong to the restricted- or unrestricted-SMS treatment groups, the framing of the information sent to jobseekers via SMS follows a standard structure and is limited to the description of the occupation and contact information ${ }^{10}$.

In total, 1,280 individuals were randomly assigned from June 22 to September 1, 2009 to four different groups, of which 354 corresponded to the control group $\left(D^{c}\right), 344$ to the standard non-digital treatment group $\left(D^{T 1}\right), 188$ to the restricted-SMS group $\left(D^{T 2}\right)$ and 303 to the unrestricted-SMS treatment group $\left(D^{T 3}\right)$. By comparing the treatment impacts across these different experimental groups, we are able to evaluate the overall impact of CIL-PROEMPLEO on the employment status of registered participants, evaluate the effectiveness of adopting digital technology (i.e., SMS) in labor-market intermediation, and test the impact of expanding the set of information available to jobseekers while holding fixed the information technology.

\section{Data and baseline equivalence}

Baseline and follow-up information were collected following standard labor-market surveys. The former contain information for 1,189 individuals, which implies an attrition rate of 7 percent relative to the original sampling design. The low rate of attrition was similar in all treatment groups, and it is not statistically related to any particular socio-demographic vari$a_{b l e}{ }^{11}$. This feature adds to the quality of the dataset used in this study since attrition bias is common in these types of settings. The follow-up dataset was collected right after the intervention ended. Since assignment into the program lasted from June 22 to September 1, 2009, the follow-up questionnaire and field work were carefully assembled to align the information from all individuals to the same time reference (i.e., 3 months after assignment). All 1,189 individuals who provided information in the baseline period were also able to participate in the follow-up survey. 
A critical step in the estimation of the causal treatment effects is to analyze the effectiveness of randomization in balancing the distribution of covariates across all treatment groups. Table 2 depicts baseline socio-demographic and labor-market information for all experimental groups, following a customized survey implemented right after the registration process. Columns 1 to 4 show descriptive statistics for each one of the four experimental groups, while columns 5 and 6 show the p-values for the $t$-test (treatment versus control) and the F-test of equality of means across all four experimental groups.

Panel A shows that the average individual in our sample has completed high-school education, is younger than 30 years old, and single. There is a slight disproportion in the rate of enrollment by gender, as 55 percent of registered users are men. Only 30 percent of users have offspring, which indicates the average user of the public intermediation is relatively young. Moreover, an analysis of household indicators reveal that the average individual in this data has access to basic infrastructure and own household assets. The p-values for all variables, except for age, do not reject the null hypothesis of the equality of means across all experimental groups.

Panel B reports basic statistics for a rich set of baseline labor-market characteristics. The unemployment spells for all groups is statistically balanced (94 days), which constitutes an important piece of information since the reliability of several nonexperimental studies in this area has been questioned because they exploited only variation of intermediation usage without controlling for the timing and duration of the unemployment spell (see for instance Thomas 1997). Moreover, 80 percent of the sample has previous job experience, mainly in the private sector, while 12 percent are considered as a discouraged worker. For those working at baseline, the average monthly income is 656 soles. Around one fifth of the sample had fringe benefits including health insurance and pension plans, while 50 percent worked as white-collar workers. Similar job characteristics are found for those who did not work at baseline but had worked in the past. Most important, the p-values of the F-test for the equality of means are above 0.05 for all variables except for the share of people who had worked under formal contracts.

Panel C reports novel information on ICT usage and job search strategies among jobseekers participating in public labor-market intermediation. The average number of search methods used by the sample is close to two. We find that 96 percent of the sample regularly use mobile phones, while 49 percent do so for job search purposes, and in particular, to contact prospective employers (57 percent), private (26 percent) and public (11 percent) labor-market intermediaries. Further, 84 percent of the sample has experience using the Internet, which is a relatively high percentage with respect to the population. Sixty-one percent of the sample used the Internet for job search purposes. Importantly, 4 out of 5 Internet-based searchers access the Internet from Internet café shops, where for a small amount of money they can rent computers with online access. Only 25 percent of the sample access Internet from home. Moreover, the data show that, on average, our sample spent 0.9 hours-per-week on public search channels, which accounts for only 20 percent of the total weekly search time. This means that job search in Peru is mainly done outside of the public intermediation system since the weekly (average) number of hours devoted to active job search is 4.5. The p-value of the F-test for the equality of means does not reject the equality of means for all ICT- 
Table 2 Summary statistics by treatment status. Digital Labor-market Intermediation Program, Lima 2009-2010

\begin{tabular}{|c|c|c|c|c|c|c|}
\hline \multirow[b]{3}{*}{ Baseline variables } & \multicolumn{4}{|c|}{ Treatment groups } & \multirow[b]{2}{*}{$\begin{array}{l}\mathrm{p} \text {-value } \\
\text { of } t \text {-test }\end{array}$} & \multirow[b]{2}{*}{$\begin{array}{l}\mathrm{p} \text {-value } \\
\text { of } \mathrm{F} \text { test }\end{array}$} \\
\hline & Non-digital T1 & Digital T2 & Digital T3 & Control & & \\
\hline & $D^{T 1}$ & $D^{T 2}$ & $D^{T 3}$ & $D^{c}$ & $\begin{array}{l}\text { Treatment = } \\
\text { Control }\end{array}$ & $\begin{array}{l}{\left[D^{T 1}=D^{T 2}=\right.} \\
\left.D^{T 3}=D_{C}\right]\end{array}$ \\
\hline \multicolumn{7}{|l|}{ A. Socio-demographic } \\
\hline Sex (1 = male) & 0.57 & 0.52 & 0.55 & 0.54 & 0.62 & 0.65 \\
\hline Age & 27.04 & 25.33 & 26.27 & 25.55 & 0.01 & 0.01 \\
\hline Years of schooling & 12.15 & 12.09 & 12.06 & 11.94 & 0.36 & 0.36 \\
\hline Single & 0.71 & 0.76 & 0.73 & 0.73 & 0.82 & 0.46 \\
\hline Have children & 0.32 & 0.26 & 0.32 & 0.26 & 0.14 & 0.22 \\
\hline Number of children & 0.55 & 0.39 & 0.55 & 0.45 & 0.24 & 0.12 \\
\hline Migrant & 0.27 & 0.29 & 0.26 & 0.25 & 0.48 & 0.75 \\
\hline Access to flush toilet & 0.93 & 0.91 & 0.93 & 0.95 & 0.11 & 0.29 \\
\hline Access to safe water & 0.94 & 0.94 & 0.93 & 0.94 & 0.40 & 0.39 \\
\hline Poverty index & 0.06 & -0.01 & -0.02 & 0.03 & 0.68 & 0.64 \\
\hline \multicolumn{7}{|l|}{ B. Labor-market experience } \\
\hline Worked ever & 0.81 & 0.80 & 0.82 & 0.82 & 0.91 & 0.97 \\
\hline Discouraged worker & 0.11 & 0.14 & 0.13 & 0.13 & 0.85 & 0.85 \\
\hline Unemployment duration (days) & 75 & 105 & 104 & 99 & 0.60 & 0.22 \\
\hline \multicolumn{7}{|l|}{ Characteristics of job at baseline } \\
\hline Monthly income (in soles) & 604 & 688 & 689 & 650 & 0.81 & 0.24 \\
\hline Had formal contract & 0.35 & 0.37 & 0.31 & 0.33 & 0.84 & 0.79 \\
\hline White-collar worker & 0.55 & 0.44 & 0.50 & 0.48 & 0.53 & 0.42 \\
\hline Had health insurance & 0.26 & 0.24 & 0.19 & 0.20 & 0.18 & 0.50 \\
\hline Had pension plan & 0.26 & 0.23 & 0.23 & 0.20 & 0.32 & 0.68 \\
\hline \multicolumn{7}{|l|}{ Characteristics of last job } \\
\hline Monthly income (in soles) & 659 & 664 & 691 & 729 & 0.28 & 0.70 \\
\hline Had formal contract & 0.49 & 0.60 & 0.67 & 0.54 & 0.28 & 0.01 \\
\hline White-collar worker & 0.65 & 0.76 & 0.69 & 0.74 & 0.25 & 0.20 \\
\hline Had health insurance & 0.28 & 0.37 & 0.35 & 0.30 & 0.46 & 0.39 \\
\hline Had pension plan & 0.29 & 0.38 & 0.35 & 0.32 & 0.70 & 0.49 \\
\hline \multicolumn{7}{|c|}{ C. Digital technologies and job search } \\
\hline Number of search methods & 1.69 & 1.56 & 1.68 & 1.67 & 0.90 & 0.72 \\
\hline $\begin{array}{l}\text { Number of hours-week } \\
\text { job search }\end{array}$ & 5.68 & 5.18 & 5.48 & 5.68 & 0.63 & 0.79 \\
\hline $\begin{array}{l}\text { Number of hours-week } \\
\text { in public channels }\end{array}$ & 0.77 & 1.01 & 0.80 & 0.82 & 0.90 & 0.65 \\
\hline $\begin{array}{l}\text { Number of hours-week } \\
\text { in private channels }\end{array}$ & 4.90 & 4.01 & 4.67 & 4.84 & 0.52 & 0.28 \\
\hline Use cell phone & 0.95 & 0.95 & 0.96 & 0.97 & 0.14 & 0.43 \\
\hline Use cell phone for job search & 0.51 & 0.49 & 0.49 & 0.46 & 0.37 & 0.79 \\
\hline $\begin{array}{l}\text { Cell phone to contact } \\
\text { prospective employers }\end{array}$ & 0.55 & 0.57 & 0.57 & 0.60 & 0.39 & 0.83 \\
\hline $\begin{array}{l}\text { Cell phone to contact } \\
\text { public LMls }\end{array}$ & 0.09 & 0.11 & 0.13 & 0.12 & 0.74 & 0.65 \\
\hline
\end{tabular}


Table 2 Summary statistics by treatment status. Digital Labor-market Intermediation Program, Lima 2009-2010 (Continued)

\begin{tabular}{|c|c|c|c|c|c|c|}
\hline $\begin{array}{l}\text { Cell phone to contact } \\
\text { private LMls }\end{array}$ & 0.27 & 0.28 & 0.25 & 0.24 & 0.47 & 0.85 \\
\hline Use internet & 0.83 & 0.85 & 0.84 & 0.84 & 0.98 & 0.86 \\
\hline Use internet for job search & 0.60 & 0.62 & 0.61 & 0.62 & 0.63 & 0.91 \\
\hline Access internet from home & 0.24 & 0.29 & 0.24 & 0.20 & 0.12 & 0.30 \\
\hline $\begin{array}{l}\text { Access internet from } \\
\text { internet cafes }\end{array}$ & 0.74 & 0.70 & 0.74 & 0.79 & 0.13 & 0.35 \\
\hline Access internet from work & 0.02 & 0.01 & 0.01 & 0.01 & 0.83 & 0.62 \\
\hline$N$ & 345 & 188 & 303 & 354 & & \\
\hline
\end{tabular}

Notes: The test of equal means for the experimental sample is based on a regression with treatment indicators on the right-hand side. $D^{T 1}$ refers to the traditional treatment group, $D^{T 2}$ to the restricted-SMS treatment group, $D^{T 3}$ to the unrestricted-SMS treatment group, and $D^{C}$ to the control group. Labor-market characteristics of job at baseline and last job are calculated conditional on employment status.

related variables. This result is important because it shows that all groups can potentially have the same access to the Internet version of the CIL-PROEMPLEO labormarket intermediation program.

In sum, the statistical analyses performed on a large set of personal and household covariates suggest that the sample of individuals assigned to all different groups were drawn from the same population. There are some few variables, however, that show some differences among the treatment groups. We therefore control for baseline covariates in the regression results.

We use the 2007 wave of the Peruvian household survey, Encuesta Nacional de Hogares (ENAHO), conducted yearly by Peru's national statistical agency, the Instituto Nacional de Estadistica e Informatica to compare differences with respect to our experimental sample. We do not observe striking differences in socio-demographic and economic characteristics between these two populations. We observe that the CIL-PROEMPLEO experimental units are somewhat younger, more educated, and have somewhat better economic status relative to the general unemployed population. Yet, there is one exception to this assessment: the unemployment spell duration is quite different for these two populations. While the general population report 3.38 weeks of unemployment, participants in the CIL-PROEMPLEO program report 13.42 weeks. This large difference is in line with international evidence that reports that public employment services are disproportionally populated with unemployed individuals with chronic problems of employability (e.g., Autor 2001 and Thomas 1997) ${ }^{12}$.

\section{Determinants of digital job search in Peru}

In this section, we use the baseline information to assess the determinants of digital labor-market intermediation for our sample of jobseekers irrespective of their treatment assignment. This analysis sheds light on the role of socio-demographic and labormarket characteristics on influencing digital job search, the relationship between Internet and mobile-phone job search channels, and how previous exposure to digital technology affects current digital job search. 
Table 3 shows the marginal effects from a probit model that estimates the likelihood of digital job search conditional on a rich set of covariates. Each column corresponds to a different outcome of interest. In column 1, the dependent variable takes the value 1 for those individuals who have used either Internet or mobile phones for job search purposes, 0 otherwise, while columns 2 and 3 considers Internet and mobile phone job search channels separately. Standard errors are presented in parentheses.

By looking at Panel A in column 1, one is tempted to conclude that individuals' socio-demographic characteristics seem to play no role on the likelihood of (overall) digital job search in metropolitan Lima since no variable is statistically significant at the 5 percent level. Yet, a closer look at columns 2 and 3 reveals that indeed some personal characteristics matter depending on the specific digital channel used. Two variables emerge as statistically significant predictors for Internet job search: presence of offspring and poverty status, the former possibly associated with spillover effects from children's exposure to Internet at schools and the latter associated with barriers to technology access due to income constrains. In fact, column 2 shows that the likelihood of using the Internet for job search purposes is almost 15 percentage points lower for poor households than that for non-poor ones and 19 percentage points higher for individuals with offspring relative to those without them. The positive relationship between Internet job search and income is in line with international evidence for developed countries (e.g., Stevenson 2009). Column 3, on the other hand, shows that gender, schooling attainment, poverty and migration status of jobseekers matters for mobile phone job search channel. Men are 10 percentage points more likely to search for jobs using mobile phones than are women, and an extra year of schooling is associated with 1.6 higher percentage points for mobile-phone job search. Likewise, the poor (and migrants) are 14 (and 9) percentage points more likely than non-poor (non-migrants) to use mobile phones during the job search process. Overall, these results suggest that poverty status is the main factor that differentiates the use of mobile phones from the Internet when selecting a job search channel. From a policy perspective, this result highlights the importance of mobile phones for vulnerable populations that cannot access the Internet in developing countries due to income barriers.

By turning our attention to Panel B, one observes that job seekers who have previous job experience and are optimistic about future job-market prospects are disproportionally more likely to use both Internet and mobile phone channels for job search purposes. Those who had never worked show a 30-percentage point lower probability of using digital job search compared to those with previous job experience, while jobseekers that are optimistic about the probability of finding a job in the near future are 16 percentage points more likely to search for jobs using digital technologies. The former result suggests that past labor-market experiences have made workers more aware of the possibilities of digital technologies, while the latter suggests a virtuous circle between digital labor-market intermediation and job gain expectations in developing settings (Dammert et al. 2013). Finally, no other labor-market variable, such as the type of worker or job-quality attributes, matters.

In Panels $\mathrm{C}$ and $\mathrm{D}$, one observes how past exposure to the Internet and mobile phones affects the likelihood of using them for job search purposes. The results show that digital experience does not matter for mobile phones searchers. In fact, having computer and Internet literacy or owning a mobile phone for a few months, three or more than five years, does not make any difference in the usage of mobile phones for 
Table 3 Determinants of digital job search, probit marginal estimates (baseline data). Labor-market Intermediation Program, Lima 2009-2010

\begin{tabular}{|c|c|c|c|}
\hline & \multicolumn{3}{|l|}{ Marginal effects } \\
\hline & $\begin{array}{l}\text { Digital internet + } \\
\text { cell phones }\end{array}$ & Internet & Cell phones \\
\hline \multicolumn{4}{|l|}{ A. Socio-demographic characteristics } \\
\hline \multirow[t]{2}{*}{ Gender ( $1=$ men, 0 = women $)$} & 0.023 & -0.026 & $0.097^{* * *}$ \\
\hline & $(0.028)$ & $(0.036)$ & $(0.032)$ \\
\hline \multirow[t]{2}{*}{ Age } & -0.003 & 0.000 & -0.004 \\
\hline & $(0.002)$ & $(0.003)$ & $(0.003)$ \\
\hline \multirow[t]{2}{*}{ Single } & 0.032 & 0.064 & -0.038 \\
\hline & $(0.047)$ & $(0.063)$ & $(0.053)$ \\
\hline \multirow[t]{2}{*}{ Has children } & $0.105^{*}$ & $0.188^{* *}$ & -0.006 \\
\hline & $(0.058)$ & $(0.081)$ & $(0.076)$ \\
\hline \multirow[t]{2}{*}{ Number of children } & -0.028 & $-0.076^{*}$ & -0.000 \\
\hline & $(0.029)$ & $(0.041)$ & $(0.036)$ \\
\hline \multirow[t]{2}{*}{ Migrant } & 0.065 & 0.062 & $0.087^{*}$ \\
\hline & $(0.043)$ & $(0.061)$ & $(0.053)$ \\
\hline \multirow[t]{2}{*}{ Years from migration } & -0.000 & -0.000 & -0.000 \\
\hline & $(0.003)$ & $(0.004)$ & $(0.003)$ \\
\hline \multirow[t]{2}{*}{ Years of schooling } & 0.007 & 0.004 & $0.016^{* *}$ \\
\hline & $(0.048)$ & $(0.007)$ & $(0.006)$ \\
\hline \multirow[t]{2}{*}{ Poor } & 0.007 & $-0.145^{* *}$ & $0.141^{* * *}$ \\
\hline & $(0.048)$ & $(0.063)$ & $(0.054)$ \\
\hline \multirow[t]{2}{*}{ Less poor } & -0.036 & $-0.095^{*}$ & 0.066 \\
\hline & $(0.041)$ & $(0.052)$ & $(0.047)$ \\
\hline \multicolumn{4}{|l|}{ B. Labor-market characteristics } \\
\hline \multirow[t]{2}{*}{ Worked under formal contract } & 0.021 & 0.038 & -0.014 \\
\hline & $(0.038)$ & $(0.050)$ & $(0.043)$ \\
\hline \multirow[t]{2}{*}{ Had pension plan } & 0.084 & 0.048 & 0.006 \\
\hline & $(0.071)$ & $(0.101)$ & $(0.089)$ \\
\hline \multirow[t]{2}{*}{ Had health insurance } & 0.007 & 0.077 & 0.023 \\
\hline & $(0.078)$ & $(0.095)$ & $(0.088)$ \\
\hline \multirow[t]{2}{*}{ Worked as blue-collar } & -0.009 & 0.000 & -0.011 \\
\hline & $(0.035)$ & $(0.047)$ & $(0.039)$ \\
\hline \multirow[t]{2}{*}{ Never work } & $-0.283^{* * *}$ & $-0.134^{* *}$ & $-0.293^{* * *}$ \\
\hline & $(0.047)$ & $(0.054)$ & $(0.042)$ \\
\hline \multirow[t]{2}{*}{ Job gain expectations ( $1=$ high, $0=$ otherwise $)$} & $0.162^{* * *}$ & $0.159^{* * *}$ & $0.075^{* *}$ \\
\hline & $(0.031)$ & $(0.038)$ & $(0.034)$ \\
\hline \multicolumn{4}{|l|}{ C. Cell phones experience } \\
\hline \multirow[t]{2}{*}{ Up to one year } & $0.097^{* *}$ & $0.105^{*}$ & $0.097^{*}$ \\
\hline & $(0.036)$ & $(0.054)$ & $(0.050)$ \\
\hline \multirow[t]{2}{*}{ Between one and three years } & 0.043 & 0.023 & 0.025 \\
\hline & $(0.029)$ & $(0.039)$ & $(0.036)$ \\
\hline \multicolumn{4}{|l|}{ D. Internet experience } \\
\hline \multirow[t]{2}{*}{ Has computer at home } & $0.279 * * *$ & $0.521^{* * *}$ & -0.124 \\
\hline & $(0.032)$ & $(0.033)$ & $(0.084)$ \\
\hline
\end{tabular}


Table 3 Determinants of digital job search, probit marginal estimates (baseline data). Labor-market Intermediation Program, Lima 2009-2010 (Continued)

\begin{tabular}{|c|c|c|c|}
\hline \multirow[t]{2}{*}{ Use computer less than three years } & 0.005 & $0.148^{* *}$ & -0.092 \\
\hline & $(0.060)$ & $(0.067)$ & $(0.069)$ \\
\hline \multirow[t]{2}{*}{ Use computer between three and five years } & -0.031 & 0.046 & -0.053 \\
\hline & $(0.063)$ & $(0.072)$ & $(0.071)$ \\
\hline \multirow[t]{2}{*}{ Use computer more than 5 years } & $0.117^{* *}$ & $0.220 * * *$ & -0.010 \\
\hline & $(0.052)$ & $(0.063)$ & $(0.070)$ \\
\hline \multirow[t]{2}{*}{ Internet café in the neighborhood } & $0.331^{* * *}$ & $0.688^{* * *}$ & -0.066 \\
\hline & $(0.073)$ & $(0.055)$ & $(0.081)$ \\
\hline \multirow[t]{2}{*}{ Internet café one block away from neighborhood } & $0.095^{* *}$ & 0.062 & 0.067 \\
\hline & $(0.040)$ & $(0.052)$ & $(0.051)$ \\
\hline \multirow[t]{2}{*}{ Internet café one to three blocks away from neighborhood } & 0.016 & 0.005 & 0.021 \\
\hline & $(0.043)$ & $(0.053)$ & $(0.053)$ \\
\hline \multirow[t]{2}{*}{ Internet café is 12 to 24 months old } & 0.007 & 0.086 & -0.083 \\
\hline & $(0.063)$ & $(0.070)$ & $(0.070)$ \\
\hline \multirow[t]{2}{*}{ Internet café is more than 24 months old } & -0.029 & 0.032 & 0.007 \\
\hline & $(0.047)$ & $(0.057)$ & $(0.053)$ \\
\hline \multicolumn{4}{|l|}{ E. Search channels } \\
\hline \multirow[t]{2}{*}{ Cell phone job search } & - - & $0.349 * * *$ & -—- \\
\hline & & $(0.033)$ & - - \\
\hline \multirow[t]{2}{*}{ Internet job search } & -—— & -—- & $0.393^{* * *}$ \\
\hline & & - & $(0.035)$ \\
\hline $\mathrm{N}$ & 1188 & 1188 & 1188 \\
\hline
\end{tabular}

Notes: Standard errors in parentheses. Marginal effects from probit estimates using baseline data. The 'digital' outcome is defined as a dummy variable that takes the value 1 for those who use Internet or cell phones for job search activities, 0 otherwise. ${ }^{* * *}$ statistically significant at $1 \%,{ }^{* *}$ statistically significant at $5 \%,{ }^{*}$ statistically significant at $10 \%$.

job search purposes. On the contrary, Internet-based job search is greatly affected by the availability of a computer at home (likelihood increases by 52 percentage points), length of computer experience ( 22 percentage point increase for those who have used a computer for more than five years), and the existence of Internet cafe shops in the neighborhood (69 percentage points). Evidence on the first two variables is not surprising and it is in line with findings from other studies that are based on data from developed countries (e.g., Stevenson 2009, Autor 2001). The last variable, however, provides new insights on the growing importance of Internet cafes in developing settings. This type of business has blossomed in recent years, although its impacts on the marketplace are practically unknown. From a policy perspective, this result suggests that providing incentives for the expansion of this type of small business might improve the efficiency of the labor markets in developing countries.

Finally, Panel E shows a positive correlation between Internet and mobile-phone search channels. The likelihood of using cell phones for job search purposes is 40 percentage points higher for individuals who use the Internet for job search relative to those who do not, while it reaches 35 percent in the other direction.

In sum, this section has uncovered evidence on key covariates that affect the access and usage of digital job search channels in Peru. Poverty and the lack of availability of Internet cafes seems to be the main barriers for Internet-based job search, while the 
presence of offspring, a computer-at-home, labor-market experience and high expectations on job gain prospects are positively related to this activity. The use of mobile phones for job search purposes, on the other hand, seems to be more idiosyncratic with respect to Internet-based search, although it is clear that disadvantaged men and migrant individuals are more prone to use it. Only two variables have a consistent positive effect for both digital channels: labor-market experience and job gain expectations, variables that are usually overlooked in the analysis of digital job-search channels.

\section{Empirical framework and results}

To estimate the overall effectiveness of public labor intermediation in Peru we implement a standard parametric OLS regression for individual $i$ in experimental (day) group $j$,

$$
Y_{i j}=\beta_{0}+\beta_{1} D_{i}+X_{i j}{ }^{\prime} \beta_{2}+\eta_{j}+\varepsilon_{i j},
$$

where $Y_{i j}$ is the particular outcome of interest (employment), $D_{i}$ denotes a treatment indicator that receives 1 for all individuals subject to labor intermediation independently of the information channel and information set they were assigned, 0 for those in the control group. $X_{i j}$ denotes a set of socio-demographic and labor-market baseline covariates, while $\varepsilon_{i j}$ is the error term. Given that we have as many experimental sets as the different days that the experimental sampling lasted, we incorporate experimental group (date) fixed effects, $\eta_{j}$, to control for intra-day variation in the treatment allocation. The coefficient of interest is $\beta_{1}$ and represents an intent-to-treat parameter. The main outcome of interest is employment in the month of reference. In our context, regression analysis is motivated by the availability of a rich set of baseline covariates that could reduce the size of the standard errors for the point estimates, the need to incorporate clustered standard errors due to intra-day variation in the random allocation, and a multiple treatment design that can be incorporated smoothly within this framework ${ }^{13}$.

To evaluate the effectiveness of adopting digital technology in labor-market intermediation along with varying sets of information available to jobseekers, we expand equation (1) and implement the following complementary model,

$$
Y_{i j}=\beta_{0}+\beta_{1} D_{i}^{T_{1}}+\beta_{2} D_{i}^{T_{2}}+\beta_{3} D_{i}^{T 3}+X_{i j}{ }^{\prime} \beta_{4}+\eta_{j}+\varepsilon_{i j},
$$

where $D_{i}^{T 1}, D_{i}^{T 2}$ and $D_{i}^{T 3}$ denote treatment indicators for the traditional, restrictedSMS, and unrestricted-SMS treatment groups, respectively. The base category is the control group. The coefficients $\beta_{1}, \beta_{2}$, and $\beta_{3}$ represent intent-to-treat parameters of interest. By comparing the magnitude and significance of $\beta_{1}$ and $\beta_{2}$, we are able to test the impacts of digital intermediation holding fixed the set of information, while by comparing $\beta_{2}$ and $\beta_{3}$ we test the impacts of expanding the set of information while holding fixed the information technology. Given the 3-month treatment duration, the follow-up survey asks individuals to respond on their employment status each month after assignment to treatment. Thus, we report three different estimates corresponding to the first, second and third month following the treatment assignment.

\subsection{Main results}

Table 4 reports the OLS short-run impacts of public labor-market intermediation on employment status one, two and three months following the intervention. The upper 
Table 4 Labor market intermediation on employment outcome. Labor-Market Intermediation Program, Lima 2009-2010

\begin{tabular}{|c|c|c|c|c|c|c|}
\hline \multirow{2}{*}{ Dep variable: employment } & \multicolumn{2}{|c|}{ Month \# 1} & \multicolumn{2}{|c|}{ Month \# 2} & \multicolumn{2}{|c|}{ Month \# 3} \\
\hline & & & & & & \\
\hline \multirow[t]{2}{*}{ Overall treatment } & $0.066^{* *}$ & $0.062^{* *}$ & $0.056^{*}$ & $0.055^{*}$ & 0.003 & -0.002 \\
\hline & $(0.032)$ & $(0.027)$ & $(0.032)$ & $(0.031)$ & $(0.031)$ & $(0.033)$ \\
\hline \multicolumn{7}{|l|}{ Type of treatment } \\
\hline \multirow[t]{2}{*}{ Traditional treatment $\left(\mathrm{D}^{\top 1}\right)$} & 0.041 & 0.034 & 0.046 & 0.040 & -0.018 & -0.034 \\
\hline & $(0.039)$ & $(0.035)$ & $(0.038)$ & $(0.036)$ & $(0.038)$ & $(0.044)$ \\
\hline \multirow[t]{2}{*}{ Restricted-SMS treatment $\left(\mathrm{D}^{\mathrm{T} 2}\right)$} & $0.081^{*}$ & $0.083^{*}$ & 0.057 & 0.060 & 0.034 & 0.034 \\
\hline & $(0.046)$ & $(0.042)$ & $(0.046)$ & $(0.046)$ & $(0.045)$ & $(0.045)$ \\
\hline \multirow[t]{2}{*}{ Unrestricted-SMS treatment $\left(D^{T 3}\right)$} & $0.086^{* *}$ & $0.081^{* *}$ & $0.067^{*}$ & $0.069^{*}$ & 0.008 & 0.008 \\
\hline & $(0.040)$ & $(0.032)$ & $(0.039)$ & $(0.037)$ & $(0.039)$ & $(0.035)$ \\
\hline$p$-value of F-test: $D^{T 1}=D^{T 2}=D^{T 3}$ & 0.478 & 0.381 & 0.876 & 0.712 & 0.493 & 0.334 \\
\hline N & 1118 & 1118 & 1118 & 1118 & 1118 & 1118 \\
\hline Covariates & No & Yes & No & Yes & No & Yes \\
\hline Experimental groups FE & No & Yes & No & Yes & No & Yes \\
\hline
\end{tabular}

Notes: Standard errrors in parenthesis. Estimates based on a parametric cross-sectional estimator. The treatment indicator takes the value 1 for those benefiting from labor-market intermediation, 0 otherwise. Socio-demographic covariates include age, gender, marital status, poverty index, whether individual has children, number of children, whether individual is migrant, number of years since migration, years of schooling. Labor-market covariates include whether individual had ever worked, whether individual had pension plan, health insurance, accident insurance, formal contract as well as blue-collar and white-collar worker indicators. Clustered standard errors by day are considered when including experimental groups fixed effects in columns 2,4 , and $6 .{ }^{* * *}$ statistically significant at $1 \%,{ }^{* *}$ statistically significant at $5 \%,{ }^{*}$ statistically significant at $10 \%$.

panel shows the overall impacts (equation 1) without considering particular treatments. Clustered standard errors by date are shown in parentheses. Results indicate that public labor-market intermediation has positive and significant employment impacts within the first month of the intervention. These effects are somewhat above 6 percentage points and statistically significant at the 5 percent level for the first month following labor-market intermediation ${ }^{14}$. This impact equals a 17 percent increase with respect to the baseline mean outcome. A comparison of columns 1 and 2 shows that these positive effects are robust to the inclusion of a rich set of baseline covariates and experimental groups fixed effects, which is expected given that randomization at the individual level has led the balance of baseline covariates between the treatment and control group individuals as shown in Table 2.

The magnitude and statistical significance of the impacts, however, lessens two and three months after treatment. Columns 3 to 6 show that the magnitude of the treatment effects reaches 5.5 percentage points and is statistically significant at the 10 percent level two months following the intervention. For the third month, no statistically significant impacts are observed. Two features related to this intervention might explain this profile for the employment impacts. First, we are facing a short-term intervention since control group individuals were left out of treatment for only three months, and thus everyone in the sample, irrespective of the random assignment, was subject to the same standard non-digital labor-market intermediation beginning the fourth month. Unlike other labor-market interventions (e.g., training) that might have long-lasting effects due to human capital accumulation, the potential impacts of this (information-only) labor-market intermediation mainly happens during the treatment period. Second, in general, users of the public labor-market intermediation are 
individuals with above-average labor-market attachment problems (e.g., Autor 2001 and Thomas 1997). Thus, it is possible that those who were not able to get a job during the first two months after the start of the intervention have the least attachment to the labor market. Indeed, Figure 1 shows the work outcome profile for all treatment groups from month zero (baseline) to month 3. One can observe that both digital treatment groups show the steepest slope from baseline to the first month of intervention. After the first month, the slope flattens out sharply. On the other hand, the profile for the control group individuals shows a linear profile with smaller but consistent gains from baseline up until the third month of the intervention. Since attachment to the labor market is balanced at baseline for all treatment groups, it implies that it is just a matter of time for individuals in the control group to catch-up those individuals in the treatment groups since the value of information become less relevant over time for individuals with weaker labor market attachments. In fact, the analysis of heterogeneous impacts presented in next section shows evidence that information has differential effects depending on the labor-market attachment of jobseekers.

An alternative explanation to interpret these diminishing effects over time is the potential existence of spillover effects as jobseekers could meet in the local offices and share information with each other regarding the treatment. Indeed, the sample of unemployed job seekers has reduced by month three for both treatment and control groups. This spillover possibility, however, is unlikely particularly in a big city such as Lima where the (crowded) local offices of the Ministry of Labor receive hundreds of people throughout the day and are without the facilities to enable this type of information exchange.

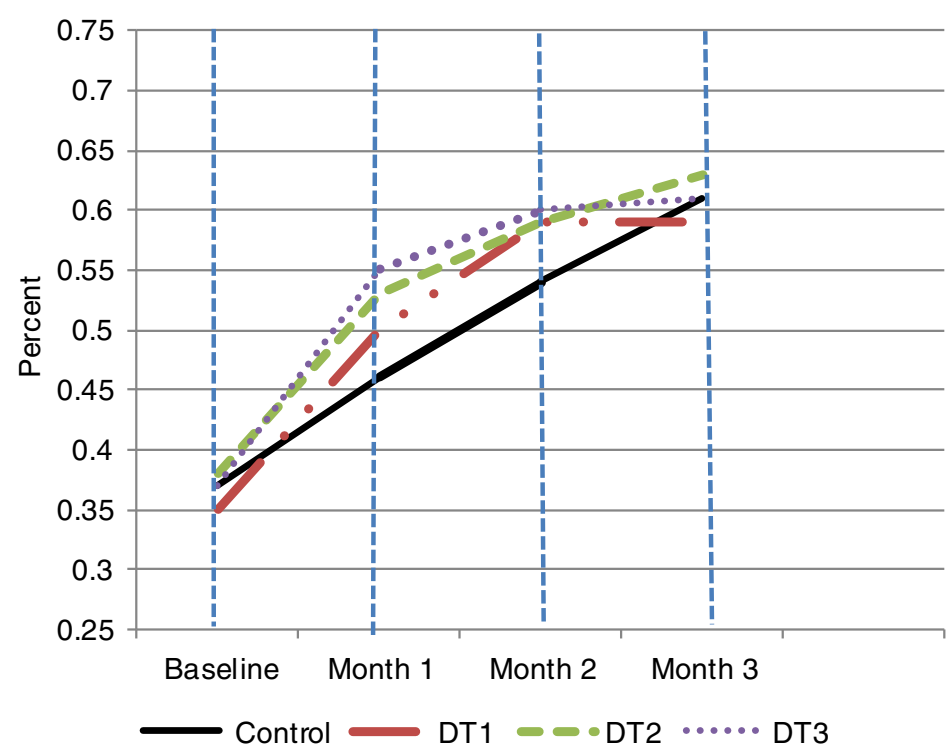

Notes: DT1, DT2, and DT3 stand for traditional treatment group, restricted-SMS treatment group, and unrestricted-SMS treatment group, respectively. Vertical axis measures the proportion of individuals with jobs.

Figure 1 Profile of working status over time by treatment status labor-market intermediation program, Lima 2009-2010. 
To disentangle the role of technology from the information set available to jobseekers, Panel B reports the intent-to-treat parameters following equation (2). Relative to the control group, the traditional treatment group $\left(D^{T 1}\right)$ shows positive but not significant treatment effects in months one (3.4 percentage points) and two (4 percentage points). On the contrary, the digital channel seems to explain the overall significant impacts we found for the public intermediation system. By looking closely at rows 3 and 4 in Table 4, one realizes that within the digital channel is the unrestricted-SMS treatment group $\left(D^{T 3}\right)$, which shows the strongest impacts in month one $(8$ percentage points) and month two (7 percentage points), both statistically significant at the 5 and 10 percent level, respectively. The magnitude of these impacts is equivalent to a slightly above 20 percent increase with respect to the baseline measure of employment. The restricted-SMS treatment group $\left(D^{T 2}\right)$, on the other hand, generally has weaker impacts and it is statistically significant only at the 10 percent level in month one, while in month two it loses statistical significance. The p-value of the F-test, however, does not reject the null hypothesis of equal coefficients. In month 3, no (statistically) significant effects are found for all individual groups. These findings are robust to the inclusion of a rich set of socio-demographic and labor-market baseline characteristics as well as the inclusion of experimental date fixed effects and clustered standard errors.

How can one explain these differential results in months one and two? According to information theory, the value of information is determined by three important factors-novelty, confidence, and ability and willingness to act based on the new information-all of which involve different forces and trade-offs (Hirshleifer and Riley 1992). In our view, the distinctiveness between restricted [public] and unrestricted [public/private] information sets involves a novelty factor since historically the standard public intermediation system has operated only with information from a limited group of low-quality firms. Thus, individuals in the unrestricted-SMS treatment group received, on average, not only more information but also qualitatively different information coming from firms that do not normally register with the public system, all of which makes more valuable the information received. Put differently, it is the value of the information generated by the novelty of the information, along the higher number of SMS received by jobseekers, which might explain the positive impacts on employment.

It is important to highlight that expanding the information set does not automatically translated into "better" outcomes since more information is not necessarily more valuable, all else held constant. One needs to recall that the typical user of the public labor market intermediation has above-average problems of employability, and therefore they could have developed strong initial beliefs about the value of the information, a genuine distrust of information coming from public sources, or both. If that is the case, they might not believe in the information or act automatically in response to more information. Evidence from behavioral economics, for example, suggests that individuals with poor past experiences have difficulty interpreting subsequent new information, ignore new information altogether or misread it as initial information expectations tend to anchor one's processing of information (Griffin and Tversky, 1992).

In sum, these findings suggest the unrestricted-SMS treatment group shows the largest employment impacts within the first two months of the intervention. Yet, we acknowledge that the relative small sample sizes of the two digital treatment groups prevent us from getting a clearer picture on the relative impacts of each treatment. 


\subsection{Heterogeneous impacts}

In this section, we analyze heterogeneous treatment impacts across three policyrelevant variables of interest: labor-market attachment, gender, and poverty status of participants. This analysis focuses on differential impacts represented by the estimated coefficient of the interaction term between the overall treatment and the covariates of interest. We do not focus on particular treatments, i.e., digital versus non-digital, since it might be asking too much from the data given the sample sizes.

First, we address whether the public intermediation system has differential employment impacts depending on participants' attachment to the labor market. This is policy relevant since adult jobseekers who have never worked are the most prone to fill the ranks of the inactive population for whom information on job opportunities might be irrelevant. We define two discrete variables of interest: 'ever worked', which is defined as 1 for those who have worked in the past, 0 otherwise; and 'full-time status', which is defined as 1 for those who had worked full-time in the past (at least 40 hours per week), 0 otherwise. The results shown in Table 5 reveal statistically significant differential impacts by work experience. Jobseekers who have ever worked in the past show a 16 percentage points difference in month one with respect to those who have never worked. Likewise, those who had worked as full-time workers show a differential impact (20 percentage points) relative to non-full time workers one month after labor market intermediation. No significant heterogeneous impacts were found for months two or three, however. These results reveal that a lack of labor-market experience constitutes a resilient barrier that is difficult to overcome by public labor-market intermediation.

Next, we assess the gender dimension as a body of empirical evidence has shown strong gender gaps against women in the Peruvian market place (e.g., Nopo 2012). The results reported in Panel $\mathrm{C}$ in Table 5 show negligible and insignificant differential impacts by gender. From a policy standpoint, this suggestive result shows that the public intermediation system is not reproducing inequalities against women in the marketplace.

We also analyze whether public labor-market intermediation show differential impacts by economic status. For that purpose, we constructed a poverty index based on more than 15 variables related to house infrastructure (e.g., access to toilet, sewage) and household assets (e.g., computer, car) after combining the data using factor analytic methods. This continuous poverty index represents a proxy for long-run economic status. We use this index to define three categories: poor (first quartile), middle (second and third quartile), and high (fourth quartile). Results reported in Panel D of Table 5 show for all interaction terms statistically insignificant effects across all treatment months. The lack of differential impacts by economic status suggests that those who are most in need do not benefit more from the public intermediation system.

Additional analyses also consider heterogeneity by education, migration status, and marital status. No statistically significant differential impacts emerge from them either.

\subsection{Job-matching efficiency: earnings effects}

The power of labor intermediation on matching efficiency has been discussed in the literature since it is expected that efficiency gains are associated with formal intermediation mechanisms that have the power to break down traditional networks and 
Table 5 Heterogenous impacts. Labor-Market Intermediation Program, Lima 2009-2010

\begin{tabular}{|c|c|c|c|c|c|c|}
\hline & \multicolumn{2}{|c|}{ Month \# 1} & \multicolumn{2}{|c|}{ Month \# 2} & \multicolumn{2}{|c|}{ Month \# 3} \\
\hline \multicolumn{7}{|l|}{ dep. var: employment } \\
\hline \multicolumn{7}{|l|}{ Panel A: work experience } \\
\hline \multirow[t]{2}{*}{ Intermediation } & -0.066 & -0.073 & 0.052 & 0.072 & -0.023 & -0.016 \\
\hline & $(0.076)$ & $(0.087)$ & $(0.075)$ & $(0.078)$ & $(0.075)$ & $(0.075)$ \\
\hline \multirow[t]{2}{*}{ Intermediation*work ever } & $0.165^{* *}$ & $0.165^{*}$ & 0.008 & -0.020 & 0.035 & 0.016 \\
\hline & $(0.084)$ & $(0.095)$ & $(0.083)$ & $(0.089)$ & $(0.082)$ & $(0.078)$ \\
\hline \multicolumn{7}{|l|}{ Panel B: full-time worker } \\
\hline \multirow[t]{2}{*}{ Intermediation } & 0.011 & 0.046 & 0.033 & 0.024 & -0.017 & -0.026 \\
\hline & $(0.037)$ & $(0.035)$ & $(0.037)$ & $(0.039)$ & $(0.036)$ & $(0.037)$ \\
\hline \multirow[t]{2}{*}{ Intermediation*full time } & $0.185^{* * *}$ & $0.205^{* *}$ & 0.069 & 0.104 & 0.058 & 0.077 \\
\hline & $(0.071)$ & $(0.082)$ & $(0.070)$ & $(0.082)$ & $(0.069)$ & $(0.067)$ \\
\hline \multicolumn{7}{|l|}{ Panel C: gender } \\
\hline \multirow[t]{2}{*}{ Intermediation } & 0.052 & 0.058 & 0.025 & 0.043 & -0.011 & 0.001 \\
\hline & $(0.047)$ & $(0.043)$ & $(0.046)$ & $(0.042)$ & $(0.046)$ & $(0.046)$ \\
\hline \multirow[t]{2}{*}{ Intermediation*men } & 0.019 & 0.007 & 0.052 & 0.022 & 0.022 & -0.007 \\
\hline & $(0.065)$ & $(0.066)$ & $(0.064)$ & $(0.068)$ & $(0.063)$ & $(0.070)$ \\
\hline \multicolumn{7}{|l|}{ Panel D: economic status } \\
\hline \multirow[t]{2}{*}{ Middle } & -0.005 & -0.020 & 0.014 & 0.013 & -0.020 & -0.028 \\
\hline & $(0.074)$ & $(0.091)$ & $(0.073)$ & $(0.088)$ & $(0.072)$ & $(0.077)$ \\
\hline \multirow[t]{2}{*}{ High } & 0.029 & -0.028 & -0.019 & -0.013 & -0.107 & -0.089 \\
\hline & $(0.078)$ & $(0.087)$ & $(0.077)$ & $(0.078)$ & $(0.076)$ & $(0.074)$ \\
\hline \multirow[t]{2}{*}{ Intermediation*poor } & 0.054 & 0.053 & 0.061 & 0.064 & -0.012 & -0.019 \\
\hline & $(0.040)$ & $(0.040)$ & $(0.039)$ & $(0.041)$ & $(0.039)$ & $(0.039)$ \\
\hline \multirow[t]{2}{*}{ Intermediation*middle } & 0.067 & 0.074 & 0.011 & 0.023 & -0.004 & 0.017 \\
\hline & $(0.077)$ & $(0.083)$ & $(0.076)$ & $(0.080)$ & $(0.076)$ & $(0.074)$ \\
\hline \multirow[t]{2}{*}{ Intermediation*high } & 0.113 & 0.091 & 0.093 & 0.059 & 0.086 & 0.052 \\
\hline & $(0.083)$ & $(0.077)$ & $(0.082)$ & $(0.082)$ & $(0.081)$ & $(0.085)$ \\
\hline$p$-value of F-test for equality of coeff & 0.819 & 0.915 & 0.750 & 0.914 & 0.546 & 0.691 \\
\hline $\mathrm{N}$ & 1118 & 1118 & 1118 & 1118 & 1118 & 1118 \\
\hline Covariates & no & yes & no & yes & no & yes \\
\hline Experimental groups FE & no & yes & no & yes & no & yes \\
\hline
\end{tabular}

Notes: Clustered standard errrors in parenthesis. Estimates based on a parametric cross-sectional estimator. The treatment indicator takes the value 1 for those benefiting from labor-market intermediation, 0 otherwise. Control variables are the same as those included in Table 3. ${ }^{* *}$ statistically significant at $1 \%,{ }^{* *}$ statistically significant at $5 \%$, *statistically significant at $10 \%$.

geographic barriers (e.g., Freeman 2002). In this regard, Bagues and Sylos (2009), for instance, found that the monthly wages of graduates from universities that had a job board for their graduates increased by 3 percent compared to those who did not. Inspired by this line of inquiry, and to separate wage impacts from employment effects, we define as a new outcome variable the conditional monthly earnings, which is defined over the subsample of individuals who are successful in getting a job. Thus, interpretation of the point estimates should be done conditional on employment. Row 1 in Table 6 shows the overall earnings impacts of public intermediation, while rows $2-5$ report the estimates for each one of the treatment groups relative to the control group. 
Table 6 Labor-market intermediation on job matching efficiency. Labor-Market Intermediation Program, Lima 2009-2010

\begin{tabular}{|c|c|c|c|c|c|c|}
\hline \multirow[b]{2}{*}{ Overall treatment } & \multicolumn{2}{|c|}{ Month \# 1} & \multicolumn{2}{|c|}{ Month \# 2} & \multicolumn{2}{|c|}{ Month \# 3} \\
\hline & 4 & -10 & 28 & 11 & 34 & 16 \\
\hline & $(28)$ & $(27)$ & $(26)$ & $(24)$ & (26) & $(24)$ \\
\hline \multicolumn{7}{|l|}{ Type of treatment } \\
\hline \multirow[t]{2}{*}{ Traditional treatement $\left(\mathrm{D}^{\mathrm{T} 1}\right)$} & 31 & -6 & 36 & 0 & 42 & 13 \\
\hline & $(34)$ & $(35)$ & $(31)$ & $(32)$ & (32) & (33) \\
\hline \multirow[t]{2}{*}{ Restricted-SMS treatment $\left(\mathrm{D}^{\top 2}\right)$} & -45 & -44 & -12 & -4 & 5 & -1 \\
\hline & (39) & $(41)$ & $(37)$ & $(37)$ & (36) & $(41)$ \\
\hline \multirow[t]{2}{*}{ Unrestricted-SMS treatment $\left(\mathrm{D}^{\top 3}\right)$} & 6 & 5 & 44 & 33 & 44 & 30 \\
\hline & (34) & (34) & $(32)$ & $(30)$ & $(32)$ & $(28)$ \\
\hline$p$-value of F-test: $D^{T 1}=D^{T 2}=D^{T 3}$ & 0.148 & 0.496 & 0.290 & 0.621 & 0.512 & 0.745 \\
\hline Covariates & No & Yes & No & Yes & No & Yes \\
\hline Experimental groups FE & No & Yes & No & Yes & No & Yes \\
\hline
\end{tabular}

Notes: Standard errrors in parenthesis. Estimates based on a parametric cross-sectional estimator conditional on working status. The treatment indicator takes the value 1 for those benefiting from labor-market intermediation, 0 otherwise.

Control covariates are the same as those included in Table 4. Clustered standard errors by day are considered when including experimental group fixed effects in columns 2,4 , and $6 .{ }^{* *}$ statistically significant at $1 \%$, **statistically significant at $5 \%$, *statistically significant at $10 \%$.

Some patterns emerge from this analysis. Firstly, the impacts for monthly earnings increase overtime, which suggest that those who got jobs in the first month of treatment have lower reservation wages than those who got jobs later on. This result is consistent with standard predictions of theoretical job search models (e.g. Mortensen 1986). However, these point estimates are not statistically significant, and thus they should be taken only as suggestive evidence. Secondly, across all three months following treatment, the unrestricted-SMS treatment group shows the largest earnings impacts (30 soles, or 22 percent of the baseline earnings), while the restricted-SMS treatment group shows the lowest. This suggestive evidence reinforces the previous discussion about the importance of the extent and scope of the information sets in labor-market intermediation, since they seem to be more relevant than the information channel itself. The availability of a larger dataset or lengthier treatment duration would have helped us to provide more definitive results. From an international perspective, the empirical literature shows ambiguous effects for LMIs on matching efficiency, with some studies showing positive impacts on earnings (e.g., Bagues and Sylos 2009) and others a zero effect (e.g., Kroft and Pope 2009).

One caveat with the estimation of job-matching treatment effects conditional on employment status is the possibility that these results are biased because we observe wages only for the employed and an individual's employment status depends on her experimental status as well as other observed and unobserved characteristics (e.g., Ham and Lalonde 1996). We assessed this potential problem by comparing observed characteristics of treatment and control units who found employment within three months of their eligibility in this program. We do not observe statistically significant differences across a rich set of covariates between these groups, and, therefore, it is not likely that treatment status is correlated with unobserved factors in the sample of employed individuals. Alternatively, we directly assessed selection bias that arises from the fact that different individuals may nonrandomly choose to work in response to labor-market intermediation by implementing the well-known two-stage least squares model (Heckman 1979). We use the randomized 
treatment assignment to instrument for the probability of having a job after collapsing the treatment groups into one ${ }^{15}$. The main findings regarding the lack of matching efficiency gains hold, and most importantly, the inverse Mills ratio is not statistically significant, suggesting that employment status is not correlated with unobservables in the sample of employed persons.

\subsection{Impacts on additional intermediate outcomes}

Motivated by the correlation between Internet and mobile-phone search channels uncovered in section 5, we analyze the causal impacts of digital labor-market intermediation on Internet-based search effort at the extensive and intensive margins. Two variables of interest are captured for the full sample: internet-based job search ( 1 for those who have used the Internet for search purposes within the three months following labor-market intermediation, 0 otherwise), and weekly hours of internet-based job search. Columns 1 and 2 in Table 7 report the results. One observes an overall positive statistical relationship between labor market intermediation and Internet-based job search. On average, individuals receiving labor-market intermediation show 6.2 percentage points increases (10 percent increase) and 0.26 more weekly hours (11 percent increase) of Internet-based job searching relative to the control group, both statistically significant at the 10 and 5 percent levels. Importantly, these results are mainly lead by the unrestricted-SMS treatment group. On average, this particular treatment lead to an increase of 7.9 percentage points and 0.33 more weekly hours of Internet-based search, both statistically significant at the 10 percent level. The non-digital and restricted-SMS treatment groups also show positive point estimates, although they are not statistically significantly different from zero. The resulting p-value of the F-test of equality of parameters among the treatment groups does not reject the null hypothesis.

To check whether digital labor-market intermediation led to crowding-out effects of traditional search channels, we analyze the causal impacts of digital intermediation on newspaper ads, friends and family referrals, among other traditional search channels, using the same parametric framework yet estimated over the sample of unemployed individuals at the time of the survey ${ }^{16}$. The results reported in column 3 in Table 7 show no evidence in this regard. The intent-to-treat parameters are not statistically significantly different from zero for all treatment groups. In contrast to evidence from developed countries that show how the lengthy penetration of Internet has led to a reallocation of search effort among various job search activities (Stevenson 2009, Kuhn and Mansour 2011), we do not find similar evidence for our short-length digital treatment intervention.

\section{Conclusion}

This study exploits a multi-treatment experimental design implemented as part of the regular (non-experimental) public intermediation system in Peru to investigate the extent to which public labor-market intermediation influences employment and job matching efficiency. Particular attention was given to investigate the interaction between the speed (digital/non-digital channels) and the scope of information (restricted/ unrestricted sets), given countervailing forces emerging from standard theoretical employment search models. We show that public labor-market intermediation causes positive and statistically significant short-run employment impacts. This positive effect, 
Table 7 Impact of labor-market intermediation on other intermediate outcomes. Labor-Market Intermediation Program, Lima 2009-2010

\begin{tabular}{llll}
\hline & $\begin{array}{l}\text { Internet-based } \\
\text { Job search }\end{array}$ & $\begin{array}{l}\text { Weekly hours } \\
\text { Internet search }\end{array}$ & $\begin{array}{l}\text { Traditional job } \\
\text { Search }\end{array}$ \\
\hline Overall treatment & $0.062^{*}$ & $0.264^{* *}$ & -0.024 \\
& $(0.032)$ & $(0.130)$ & $(0.049)$ \\
Type of treatment & & & \\
Traditional treatment $\left(\mathrm{D}^{\top 1}\right)$ & 0.049 & 0.241 & -0.007 \\
& $(0.038)$ & $(0.160)$ & $(0.065)$ \\
Restricted-SMS treatment $\left(\mathrm{D}^{\top 2}\right)$ & 0.056 & 0.186 & -0.005 \\
& $(0.046)$ & $(0.172)$ & $(0.094)$ \\
Unrestricted-SMS treatment $\left(\mathrm{D}^{\top 3}\right)$ & $0.079^{*}$ & $0.336^{*}$ & -0.054 \\
& $(0.042)$ & $(0.202)$ & $(0.082)$ \\
p-value of F-test: $\mathrm{D}^{\top 1}=\mathrm{D}^{\top 2}=\mathrm{D}^{\mathrm{T3}}$ & 0.765 & 0.792 & 0.678 \\
$\mathrm{~N}$ & 1140 & 1140 & 517 \\
Covariates & Yes & Yes & Yes \\
Experimental groups FE & Yes & Yes & Yes \\
\hline
\end{tabular}

Notes: Clustered standard errrors in parenthesis. Estimates based on a parametric cross-sectional estimator. Internet-based search outcome is captured for the full sample, and it is defined as 1 for those who have used the Internet within the three months of labor-market intermediation, 0 otherwise. Traditional job search and job expectations outcomes are captured only for the unemployed at the time of the follow-up interview. Control covariates are the same as those included in Table 4. ***statistically significant at $1 \%,{ }^{* *}$ statistically significant at $5 \%,{ }^{*}$ statistically significant at $10 \%$.

however, dissipated three months later, timing that coincides with the beginning of labor-market intermediation for the control group.

An important finding reported in this study is that, in the labor market, the scope and novelty of the information travelling through digital means seems to be important. While the impacts from traditional intermediation are not large enough to be statistically significant, the unrestricted-SMS treatment group shows statistically significant employment effects in the first two months following the intervention. Although the differential impacts among treatment groups are not sufficiently large to be statistically detected, the results suggest that integrating mobile phone technologies into traditional, public labor-market intermediation and extending the set of information available for jobseekers can constitute a cost-effective labor-market initiative as the marginal costs of providing SMS information are low. As for potential matching efficiency gains, the results suggest no statistically significant effects associated with information channels or sets. Overall, these results suggest weaker impacts for SMS technologies in the labor market relative to previous studies that mainly focused on agricultural markets and outputs. We acknowledge that our sample represents a particular subset of the unemployed population, so external validity of the findings should be taken with caution.

From a policy standpoint, this research shows the feasibility and value of integrating new information technologies into the old, traditional labor-market intermediation services. That is perhaps the main policy contribution of this research as it highlights how traditional LMIs can take advantage of the rapid expansion of mobile phone technologies and catch themselves up by using SMS applications as a delivery platform. A particular lesson emerging from this study is that the Peruvian public 
intermediation system could improve its efficiency if the restriction to operate based on a limited set of firms that have previously signed up to the system is relaxed. In this regard, jobseekers could benefit more if the public LMI operator also incorporates information generated outside the system, such as from online job boards and newspapers ads. Particular attention should be given to those who lack labor-market experience since the results show that this particular group benefits the least from public labor-market intermediation and disproportionally uses the Internet and cell phones less for job search purposes.

\section{Endnotes}

${ }^{1}$ Peru's mobile infrastructure reached a substantial coverage of 101 mobile phone subscriptions per 100 inhabitants, with 79 percent of them classified as prepaid subscriptions in 2010 World Bank (2012).

${ }^{2}$ The duration of unemployment for jobseekers using the public employment services was around 11 weeks, while for those using other job search strategies was 7 weeks.

${ }^{3}$ The information collected from jobseekers include standard demographic variables, schooling, training participation, computing knowledge, foreign-language knowledge, driver's license, labor market experience, and current labor-market situation. Firms provide contact information (address, contact name, telephone, location, etc.), detailed description of the job vacancy (work schedules, salary, location, main responsibilities and tasks), and job requirements (education, experience, computing and language knowledge, years of experience, driver's license).

${ }^{4}$ A common practice for private employment agencies in Peru is to charge each worker half of the monthly salary they would receive in the new job.

${ }^{5}$ The service is free and accessible to anyone with a computer at http:// www.empleosperu.gob.pe.

${ }^{6}$ It is estimated that 34 percent of registered jobseekers make use of this electronic version of the program (MTPS 2006).

${ }^{7}$ Thomas (1997), for example, shows that the positive relationship between public employment services use and unemployment spell duration is biased because of the lack of control for the timing of unemployment.

${ }^{8}$ The matching algorithm was able to map specific job requirements (e.g., gender, age, schooling level, prior experience, and skills) to individuals' profiles.

${ }^{9}$ According to a 2003 survey of formal firms located in metropolitan Lima, advertisement of job vacancies is mainly done via newspaper ads (54 percent).

${ }^{10} \mathrm{~A}$ (fictitious) reproduction of an SMS message says: "PROEMPLEO. Hostess wanted Restaurant Amador. Av. La Mar \#3453 Lince Tel 3038145. Contact”.

${ }^{11}$ Attrition is not driven by specific drop-out patterns of low- or high-quality jobseekers. Rather it mainly reflects the inability of surveyors to find respondents in their homes during the survey visits.

${ }^{12}$ This table is available upon request.

${ }^{13}$ An alternative option would be to implement a standard parametric difference-indifferences model. Yet, the employment outcome in the baseline period refers to the week of reference, while the follow-up data captures monthly employment for each one the first months following treatment. One should not expect, however, to have different results given the strong balance in outcomes and covariates in the baseline period. 
${ }^{14}$ The experimental point estimates are modest compared to non-experimental evidence presented by Chacaltana and Sulmont (2013) in their analysis of earlier cohorts participating in the CIL-PROEMPLEO program. These authors used a sample of 153 individuals that were successfully intermediated in April 2001 as the treatment group. The comparison group comes from a representative employment survey from which 275 nonparticipant individuals, who were unemployed in April 2001, were drawn. Some outcomes of interest were measured and compared one year later using standard parametric matching techniques. The authors show large and significant gains in wages and employment for the treatment group, relative to the control one, one year later.

${ }^{15}$ Given that both earnings and employment are endogenous variables, with only one IV, we are still identifying off of the functional form.

${ }^{16}$ In contrast to the Internet-based outcome, traditional search methods in the follow-up survey were asked only for the week of reference and only to the subsample of unemployed people.

${ }^{17} \mathrm{We}$ do not make any assumption regarding the distributions functions $F_{1}$ and $F_{2}$.

\section{Appendix: Some theoretical considerations}

We present in this section a (marginal) extension of a standard job-search model with endogenous search intensity (Mortensen 1986) to illustrate the theoretical effects of policies that aim at changing the rate at which jobseekers are informed about job openings on search intensity and exit rate from unemployment. Previous related literature has studied the effect of job offer arrival rates on the exit rate from unemployment in the context of constant individual search effort and a single job search channel. For this particular case, van den Berg (1994) shows minimal conditions on the wage offer distribution that ensure a positive effect on the exit rate associated with an increase in the job offer arrival rate. Fougère et al. (2009) extended the model by considering two channels of job-search, public and private, with endogenous search effort only along the private channel. Results from this model suggest that an increase in the public job offer arrival rate has only a positive effect on the exit rate as long as the wage offer distributions in both channels are assumed to be identical; otherwise, the direction of the effect is ambiguous.

We extended the model by considering two job search channels, public and private, with endogenous search efforts in both search channels. In contrast to Fougère et al. (2009), we consider that the job offer arrival rate via the public channel to be endogenous since the features of the public labor intermediation services we are studying suggest that individuals need to allocate a complementary search effort to make effective a job offer. In this study, the job offer arrival rate depends on the individual's search effort, the type of technology employed by the public labor mediation services, and the set of information used to match individuals to jobs. We consider an unemployed individual who does not receive any UI benefits and is actively searching for a job using both private and public labor intermediation services. Unemployed individuals using public intermediation services are contacted and informed about job openings according to a Poisson process with endogenous rate $s_{1} \lambda_{1}(\tau, \xi)$ that depends on the search intensity effort $s_{1}$ and the overall channel-specific search efficiency $\lambda_{1}$, which in turn depends on the technology used to convey the information $\tau$ and the set of information employed to match job openings $\xi$. We assume that the overall channel-specific search efficiency level can be improved with information communication technologies $\lambda_{1, \tau}>0$ and by employing a broader set of 
information on job openings $\lambda_{1, \xi}>0$ to match individuals to jobs. The arrival rate of effective job offers is defined as $q_{1} s_{1} \lambda_{1}(\tau, \xi)$, where $q_{1}$ is the probability that a job contact via public mediation service leads to a job offer.

Likewise, unemployed individuals using private job-search methods are informed about job openings at rate $s_{2} \lambda_{2}$, which depends on the search intensity effort $s_{2}$ and an overall constant channel-specific search efficiency level $\lambda_{2}$. The arrival rate of effective job offers is defined as $q_{2} s_{2} \lambda_{2}$ where $q_{2}$ is the probability that a job contact via private job-search leads to an effective job offer. Job offers along these two channels of search are characterized as random draws from wage offer distributions $F_{1}(w)$ and $F_{2}(w)$, respectively ${ }^{17}$. Search intensity effort is costly and can be summarized by the cost function $c\left(s_{1}, s_{2}\right)$ with increasing and convex arguments such that $c_{s_{i}}>0, c_{s_{i} s_{i}}>0$, $c_{s_{i} s_{j}}>0, c_{s_{i} s_{i}} c_{s_{i} s_{j}}-c_{s_{i} s_{j}}^{2}>0$. In the absence of UI benefits, as is the case here, let $z$ be the value of leisure and $r$ the discount rate. An optimal search strategy is a choice of an intensity of search effort and reservation wage $w^{*}$. Let $U$ and $W(w)$ denote the present discounted value of income when unemployed and employed, respectively. The presentdiscounted value from unemployment $U$ satisfies the bellman equation

$$
r U=\underset{s_{1}, s_{2} \geq 0}{\operatorname{aax}}\left[z-c\left(s_{1}, s_{2}\right)+q_{1} s_{1} \lambda_{1}(\tau, \xi) \int_{0}^{\infty} \max \left[0, W_{1}(x)-U\right] d F_{1}(x)+q_{2} s_{2} \lambda_{2} \int_{0}^{\infty} \max \left[0, W_{2}(x)-U\right] d F_{2}(x)\right]
$$

By applying the reservation wage property $U=W\left(w^{*}\right)=w^{*} / r$ to equation (1), we can state that the reservation wage, $w^{*}$, is the solution to

$$
w^{*}=\underset{s_{1}, s_{2} \geq 0}{\operatorname{ax}}\left[z-c\left(s_{1}, s_{2}\right)+\frac{q_{1} s_{1} \lambda_{1}(\tau, \xi)}{r} \int_{w^{*}}^{\infty}\left(x-w^{*}\right) d F_{1}(x)+\frac{q_{2} s_{2} \lambda_{2}}{r} \int_{w^{*}}^{\infty}\left(x-w^{*}\right) d F_{2}(x)\right]
$$

The first order conditions for optimal search intensity efforts $s_{1}^{*}$ and $s_{2}^{*}$ equate the marginal return and cost, and can be written as

$$
\left.\begin{array}{ll}
s_{1}: & -c_{s_{1}}+\frac{q_{1} \lambda_{1}(\tau, \xi)}{r} \int_{w^{*}}^{\infty}\left(x-w^{*}\right) d F_{1}(x)=0 \\
s_{2}: & -c_{s_{2}}+\frac{q_{2} \lambda_{2}}{r} \int_{w^{*}}^{\infty}\left(x-w^{*}\right) d F_{2}(x)=0
\end{array}\right\}
$$

The exit rate from unemployment for an individual that uses public labor intermediation services as well as alternative private job-search methods is defined as

$$
\gamma=q_{1} s_{1} \lambda_{1}(\tau, \xi)\left[1-F_{1}\left(w^{*}\right)\right]+q_{2} s_{2} \lambda_{2}\left[1-F_{2}\left(w^{*}\right)\right]
$$

The theoretical effect of policies that may affect the rate at which unemployed individuals are informed about job openings (e.g., SMS technology) on the exit rate from unemployment is defined as

$$
\frac{d \gamma}{d \tau}=\lambda_{1}(\tau, \xi) a_{1} \frac{\partial s_{1}}{\partial \tau}+s_{1} a_{1} \frac{\partial \lambda_{1}(\tau, \xi)}{\partial \tau}+\lambda_{2} a_{2} \frac{\partial s_{2}}{\partial \tau}+\left[s_{1} \lambda_{1}(\tau, \xi) \frac{\partial a_{1}}{\partial w^{*}}+s_{2} \lambda_{2} \frac{\partial a_{2}}{\partial w^{*}}\right] \frac{\partial w^{*}}{\partial \tau}
$$


where $a_{i}=q_{i}\left[1-F_{i}\left(w^{*}\right)\right]$. By construction, we know that the overall search efficiency level $\lambda_{1}$ can be improved by information technology (e.g., SMS) used to convey information on job opportunities to unemployed individuals $\partial \lambda_{1}(\tau, \xi) / \partial \tau>0$. Then, a comparative static exercise (available under request) suggest that the search effort allocated to the public job-search channel increases with the technology that improves the rate at which unemployed individuals are contacted and informed about job openings, $\partial s_{1} / \partial \tau>0$.

The intuition for this result suggest that as long as the SMS technology improves the overall search efficiency in the public search channel, those using this channel will tend to allocate higher search efforts to it. Conversely, it is expected that individuals' search efforts allocated to alternative private search channels will be crowed-out since $\partial s_{2} / \partial \tau<0$. Further, as the technology improves the rate at which individuals are informed about job openings, we expect a more patient unemployed individual waiting to consider a better wage offer, as the increase in the reservation wage suggest, $\partial w^{*} / \partial \tau>0$. Hence, the sign of expression (5) is uncertain and clearly hinges on the magnitudes of the reservation wage response to policy and the crowding-out effect on private job-search effort. This uncertainty only has been resolved in models with a single job-search channel and a constant job offer arrival rate (van den Berg, 1994) or models with two job-search channels and an endogenous job offer arrival rate in only one channel (Fougère et al. 2009). Yet here, with endogenous job offer arrival rates in both search channels, finding conditions to tell the direction of expression (SS5) is not clear. Therefore, we have to turn to an empirical approach to gain additional insights.

\section{Competing interests}

The IZA Journal of Labor and Development is committed to the IZA Guiding Principles of Research Integrity. The authors declare that they have observed these principles.

\section{Authors' information}

Ana Dammert is an Associate Professor in the Department of Economics and the School of International Affairs at Carleton University, and a Research Fellow at the Institute for the Study of Labor (IZA), Bonn, Germany. Jose Galdo is an Associate Professor in the Department of Economics and the School of Public Policy at Carleton University, and a Research Fellow at the Institute for the Study of Labor (IZA), Bonn, Germany. Virgilio Galdo is a researcher at The World Bank. Authors' names appear in alphabetical order.

\section{Acknowledgements}

We acknowledge financial support from the Inter-American Development Bank (IADB) and the Social Sciences and Humanities Research Council of Canada (SSHRC). We thank the Ministry of Labor and Social Promotion of Peru and SASE Asociacion Civil for their logistic and institutional support. We also thank Alberto Chong, Jeffrey Kubik and Christopher Ksoll for valuable comments and suggestions, as well as audiences in Syracuse University, The University of Guelph, the $29^{\text {th }}$ European Economic Association Meeting at the University of Toulouse, the $9^{\text {th }}$ IZA-World Bank Conference in Employment and Development in Lima, and the $45^{\text {th }}$ Conference of the Canadian Economic Association at the University of Ottawa. Rene Castro and Minoru Higa provided excellent research assistance. We thank the Editor and the anonymous referee for their comments and suggestions. All errors are our own.

Responsible editor: David Lam

\section{Author details}

'Department of Economics and School of International Affairs, Carleton University, 1125 Colonel by Drive, Ottawa, Canada. ${ }^{2}$ IZA, Bonn, Germany. ${ }^{3}$ Department of Economics and School of Public Policy and Administration, Carleton University, 1125 Colonel by Drive, Ottawa, Canada. ${ }^{4}$ The World Bank, 1818 H StreetNW, Washington DC, USA.

Received: 21 January 2015 Accepted: 19 April 2015

Published online: 24 July 2015

References

Aker J (2010) Information markets near and far: mobile phones and agricultural markets in Niger. American Economic Journal-Applied Economics 2(3):46-59 
Aker J, Mbiti I (2010) Mobile phones and economic development in Africa. J Econ Perspect 24(3):207-232

Aker J and Fafchamps M (2013) Mobile Phone Coverage and Producer Markets: Evidence from West Africa. World Bank Economic Review (forthcoming).

Ashenfelter O, Ashmore D, Deschenes O (2005) Do unemployment insurance recipients actively seek work? Evidence from randomized trials in four U.S States. J Econ 125:53-75

Autor DH (2001) Wiring the labor market. J Econ Perspect 15:25-40

Autor DH (2009) The economics of labor market intermediation: An analytical framework. Chicago, University of Chicago Press, In Studies of labor market intermediation

Bagues M, Sylos M (2009) Do online labor market intermediaries matter? The impact of Alma Laurea on the university-to-work transition. In: David A (ed) Studies of labor market intermediation. University of Chicago Press, Chicago

Bishop J (1993) Improving job matches in the U.S labor market. Brook Pap Econ Act 1:335-400

Black D, Smith J, Berger M, Noel B (2003) Is the threat of reemployment services more effective than the services themselves? Experimental evidence from the UI system. Am Econ Rev 93:1313-1327

Boone J, van Ours J (2004) Effective active labor market policies. IZA Working Paper 1335.

Cahuc P, Fontaine F (2009) On the efficiency of job search with social networks. Journal of Public Economic Theory 11(3):411-439

Chacaltana J, Sulmont D. (2003) Politicas activas en el mercado laboral peruano: el potencial de la capacitacion y los servicios de empleo. Manuscript.

Dammert A, Galdo J, Galdo V (2014) Preventing dengue through mobile phones: evidence from a field experiment in Peru. J Health Econ 35:147-161

Dammert A, Galdo J, Galdo V (2013) Digital Labor-Market Intermediation and Job Expectations: Evidence from a Field Experiment. Econ Lett 120(1):112-116

Fougère D, Pradel J, Roger M (2009) Does the public employment service affect search effort and outcomes? Eur Econ Rev 53(7):846-869

Freeman R (2002) The labour market in the new information economy. Oxf Rev Econ Policy 18(3):288-305

Goyal A (2010) Information, direct access to farmers, and rural market performance in central India. American Economic Journal-Applied Economics 2(3):22-45

Griffin D, Tversky A (1992) The weighting evidence and the determinants of confidence. Cogn Psychol 24(3):411-35

Grossman S, Stigler J (1976) Information and competitive price systems. The American Economic Review Papers and Proceedings. 66(2):246-253

Ham J, Lalonde R (1996) The effect of sample selection and initial conditions in duration models: Evidence of experimental data on training. Econometrica 64(1):175-205

Heckman J (1979) Sample Selection Bias as Specification Error. Econometrica 47(1):153-61

Hirshleifer J, Riley JG (1992) The analytics of uncertainty and information. In: Cambridge surveys of economic literature. Cambridge University Press, Cambridge, New

Jensen R (2007) The digital provide: information (technology), market performance, and welfare in the south Indian fisheries sector. Q J Econ CXX11(3):879-924

Karlan D, McConnelly M, Mullainathan M \& Zinman J (2010) Getting to the top of mind: how reminders increase saving. NBER WP 16205

Kroft K, Pope D (2009) Does online search crowd out traditional search and improve matching efficiency? Evidence from Craigslist. In: Autor D (ed) Studies of labor market intermediation. University of Chicago Press, Chicago

Kuhn P, Skuterud M (2004) Internet job search and unemployment duration. Am Econ Rev 94(1):218-232

Kuhn P, Mansour M (2011) Is Internet job search still ineffective? IZA WP 5955

Meyer B (1995) Lessons from the U.S unemployment insurance experiments. J Econ Lit 33:91-131

Mortensen D, (1986) Job search and labor market analysis. In Ch. 15 of Handbook of Labor Economics, Vol. 2, O. Ashenfelter and R. Layard, eds., North-Holland.

MTPS (1998) Programa Red CIL PROEMPLEO. Ministerio de Trabajo y Promoción del Empleo.

MTPS (1999) Programa Red CIL PROEMPLEO. Ministerio de Trabajo y Promoción del Empleo.

MTPS (2006) Anuario Estadístico. Ministerio de Trabajo y Promoción del Empleo.

Nakamura AK, Shaw R, Freeman AN, Pyman A (2009) Jobs online. In: Autor D (ed) Studies of labor market intermediation. University of Chicago Press, Chicago

Ñopo H (2012) New century, old disparities: gender and ethnic earnings gaps in Latin America and the Caribbean. World Bank Publications, The World Bank

Pissarides C (2000) Equilibrium unemployment theory. 2nd Edition. The MIT Press, USA.

Pop-Eleches C, Thirumurthy H, Habyarimana J, Zivin J, Goldstein M, de Walque D, Mackeen L, Haberer J, Kimaiyo S, Sidle J, Ngare D, Bangsberg D (2011) Mobile phone technologies improve adherence to antiretroviral treatment in a resource-limited setting: A randomized controlled trial of text message reminders. AIDS 25(6):825-834

Stevenson B (2009) The Internet and job search. In: Autor D (ed) Studies of Labor Market Intermediation. University of Chicago Press, Chicago

Stigler G (1961) The Economics of information. J Polit Econ 69(3):213-225

Stigler G (1962) Information in Labor Marke. J Polit Econ 70(5):94-105, part2

Thomas J (1997) Public employment agencies and unemployment spells: reconciling the experimental and nonexperimental evidence. Ind Labor Relat Rev 50(4):667-683

van den Berg G (1994) The Effects of changes of the job offer arrival rate on the duration of unemployment. J Labor Econ 12(3):478-498

Vera R (2006) La discriminación en los procesos de selección de personal. ILO, Geneva

World Bank (2012) Information and Communications for Development: Maximizing Mobile. The World Bank, Washington, DC 